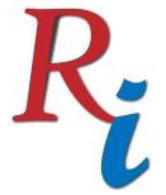

Asia Proceedings of Social Sciences

(APSS)

www.readersinsight.net/APSS

\title{
THE INFLUENCE OF CORPORATE CULTURE ON BALANCED SCORECARD USE
}

\section{Rapiah Mohamed ${ }^{*}$}

Tunku Puteri Intan School of Accountancy, College of Business Universiti Utara Malaysia, Sintok Malaysia

\section{Khalis Al-Naser}

Accounting Department, Administration and Economic College University of Mosul, Mosul

Iraq

*Corrosponding author's Email: rapiah@uum.edu.my

Peer-review under responsibility of $3^{\text {rd }}$ Asia International Multidisciplanry Conference 2019 editorial board (http://www.utm.my/asia/our-team/) (C) 2019 Published by Readers Insight Publisher, lat 306 Savoy Residencia, Block 3 F11/1,44000 Islamabad. Pakistan, info@ readersinsight.net This is an open access article under the CC BY-NC-ND license (http://creativecommons.org/licenses/by-nc-nd/4.0/). 


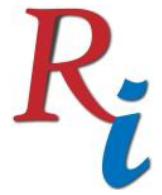

\section{Asia Proceedings of Social Sciences \\ (APSS) \\ www.readersinsight.net/APSS}

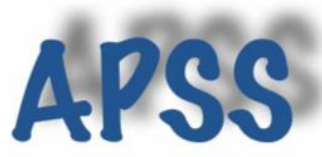

\section{Rese a r ch H i g h I igh t s}

The balanced scorecard (BSC) is a strategic performance measurement system model that was introduced by Kaplan and Norton in 1992 and since then is well received by many worldwide organisations. This research seeked to understand the influences of corporate culture on BSC usage among Iraqi manufacturing firms. The research framework of this study is based on the contingency theory. Prior literature found that corporate culture is a contingent factor that is likely to influence the design and usage of performance measurement system such as BSC, in particular related to the diversity of measurement (Henri, 2006; Franco-Santos, 2007).

It is hypothesized that a better match between BSC and contextual variables such as corporate culture, leads to increased corporate performance (Fisher, 1998; Sila, 2007), while poor fit denotes diminished performance. This study has proposed one hypothesis and results indicated that there is a positive relationship between corporate culture and the use of BSC.

\section{Graphical A bstract}

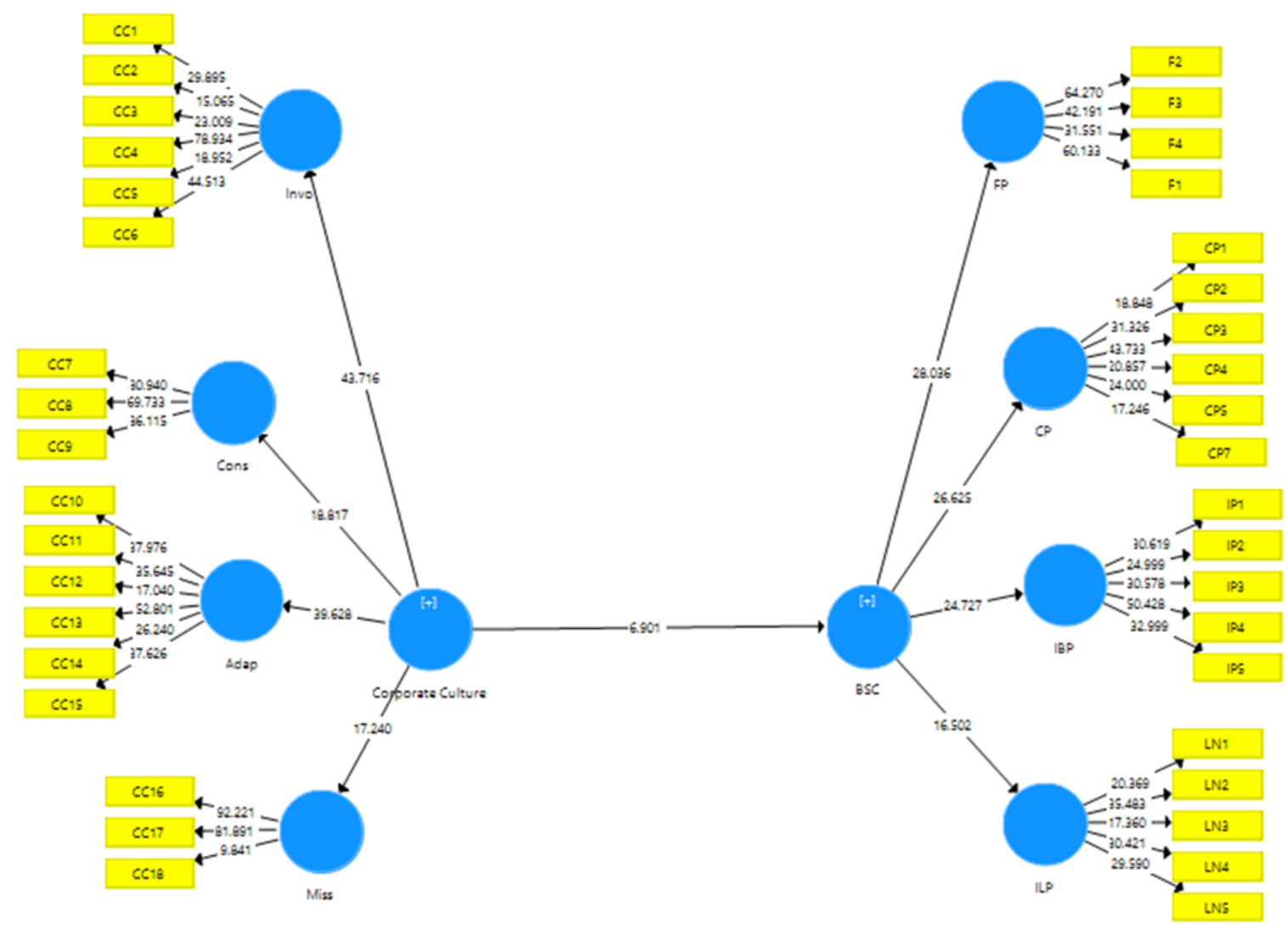

\section{Research Objectives}

Corporate culture has been overlooked in recent performance measurement system (PMS) (including BSC) studies even though numerous scholars have argued that corporate culture is a critical contingent factor that is likely to affect PMS. Therefore, an understanding of this contingent factor is necessary to examine PMS more deeply (Henri,2006). Corporate culture likely affects the use of financial and non-financial performance measures, where Henri (2006) 


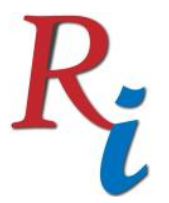

\section{Asia Proceedings of Social Sciences (APSS) \\ www.readersinsight.net/APSS}

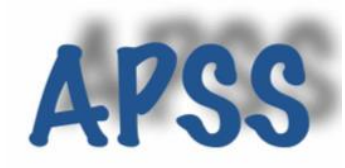

suggested that the use of PMS and the diversity of measurement are influenced by organizational culture.

By implementing BSC, the environment of a business organization is changed to a knowledgebased environment (Kaplan \& Norton, 2001). BSC has the capability to link the cause-andeffect model with tangible and intangible assets (Kaplan \& Norton, 2001). This is the core cultural element that should be inculcated for value creation. Brown (2000) suggested that embedding the values in BSC is compulsory for success. He also perceived culture as a distinct characteristic that cannot be replicated by any other organization. However, there is an evident lack of research focusing on the relationship between corporate culture and use of BSC. For example Rababah (2015) mentioned that there has been very few empirical research studies on relationship between organisational culture and BSC. Therefore, this paper is aimed to examine the relationship between corporate culture and use of BSC from the context of Iraqi.

\section{Methodology}

This study employed a quantitative research design to examine the relationship between corporate culture and BSC usage. Self administred survey method was used for data collection. Total of 301 data were collected from manufacturing companies in Iraq which represent $49.83 \%$ of the population. Majority of the respondents are male $(n=301,76.4 \%)$. Furthermore, the respondents are hold position of chief management accountants $(n=301,59.1 \%)$, chief executive officers ( $n-301,29.6 \%)$, chief controller $(n=301,7.6 \%)$, and chief financial officers $(n=301,3.7)$. Smart PLS was applied for the data analysis to test the hypothesis. A two-step analytical approach was used as suggested by Chin (2010): first, the assessment of the measurement model for reliability and validity and second, the structural model (Ringle, Wende \& Will, 2005). This paper adopted measurement of variables from previous studies. Some of the items were slightly reworded to reflect the context of current study. The BSC measured using an instrument developed by Kaplan and Norton (1996). The instrument contains 20 items measuring four dimensions: financial, customer, internal business process, and learning and growth. Finally, corporate culture was measured using four dimensions from Denison (2000).

\section{Results}

Based on the measurement model assessment, all four constructs of corporate culture ( involvement, consistency, adaptability and mission) and BSC (financial, customer, internal business and, innovation and learning) have adequate consistency reliability and their convergents were well confirmed and satisfied. From the structural model, the results show that path coefficient from CC to BSC is statistically significant with a beta $(\beta)$ value of 0.345 , t-value of 6.901 and a p-value of 0.000 significant at the $1 \%$. The results indicate that corporate culture significantly affects BSC usage in the Iraqi manufacturing companies, thus, the hypothesis is supported.

\section{Findings}

Based on the findings of the study, it showed that corporate culture does play an important role in influencing the usage of BSC in Iraqi manufacturing companies. The relationship between corporate culture and BSC usage represent an extension of contingency-based research from its organizational basis into more sociological concern (Chenhall, 2003). Literature has shown evidence that success of BSC implementation is linked with corporate culture. The four traits of corporate culture - involvement, adaptability, consistency and mission are important to 


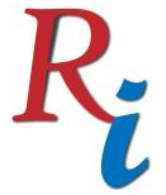

\section{Asia Proceedings of Social Sciences (APSS) \\ www.readersinsight.net/APSS}

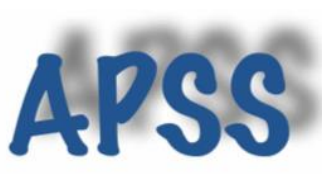

influence the diversity of measurement used in the BSC. The results implied that the company needs to has ability to respond to the perceived environment, encourage employees participation, and a clear mission to guide to achieve strategic goals. With the strong corporate culture will lead to the positive behavior and enhance company performance.

\section{References}

Brown, M. G. (2000). Winning score: How to design and implement organizational scorecards. New York: Productivity Press.

Chenhall, R. H. (2003). Management control systems design within its organizational context: findings from contingency-based research and directions for the future. Accounting, organizations and society, 28(2), 127-168.

Chin, W. W. (2010). How to write up and report PLS analyses. Handbook of partial least squares, 655690.

Denison, D. R. (2000). Organizational culture (OC): Can it be a key lever for driving organizational change. In S. Cartwright \& C. Cooper (Eds.), The handbook of organizational culture (OC) and climate (347-376). Chichester, England: Wiley.

Fisher, J. (1998). Contingency theory, management control systems and firm outcomes: Past results and future directions. Behavioral Research in Accounting, 10, 47-64.

Franco-Santos, M. (2007). The performance impact of using measurement diversity in executives' annual incentive systems (Unpublished doctoral dissertation). Cranfield University, Cranfield, United Kingdom. $\quad$ Retrieved from https://dspace.lib.cranfield.ac.uk/handle/1826/2305.

Henri, J. F. (2006). Organizational culture and performance measurement systems. Accounting, organizations and society, 31(1), 77-103.

Kaplan, R. S., \& Norton, D. P. (1992). The balanced scorecard-measures that drive performance. Harvard Business Review, 70(1), 71-79.

Kaplan, R. S., \& Norton, D. P. (1996). Linking the balanced scorecard to strategy. California management review, 39(1), 53-79.

Kaplan, R. S., \& Norton, D. P. (2001). The strategy focused organization how balanced scorecard companies thrive in the new business environment. Boston, MA: Harvard Business School Press.

Rababah, A. (2015). The relationship between cultural factors and balanced scorecard implementation. International Review of Management and Business Research. 4(4), 1208-1218.

Ringle, C., Wende, S., \& Will, A. (2005). Smart-PLS Version 2.0 M3. University of Hamburg.

Sila, I. (2007). Examining the effects of contextual factors on TQM and performance through the lens of organizational theories: An empirical study. Journal of Operations Management, 25(1), 83-109. 